\title{
PENGARUH CITRA DAN KESADARAN MEREK TERHADAP \\ KEPUTUSAN PEMBELIAN KONSUMEN PADA \\ TEH HIJAU DALAM KEMASAN SIAP MINUM \\ "NU GREEN TEA" \\ UB BAROKAH
}

\author{
Aris Budiyanto dan Sri Yanthy Yosepha \\ Mahasiswa dan Dosen Manajemen Unsurya \\ aris.budianto@gmail.com \& yosepha@universitassuryadarma.ac.id
}

\begin{abstract}
The purpose of this study is to know the influence of image, brand awareness on consumer purchasing decisions. This study uses a descriptive research which isa research describes the objects related to the decision taking generally.

In this study, a researcher takes 50 respondents as a sample by using accidental sampling which is the consumers who do purchasing decision in Nu Green Tea, should answer the questionnaires.

The finding of this study shows two independent variables which are image and brand awareness. Those have positive and significant influenced toward dependent variable that is $\mathrm{Nu}$ Green Tea's purchasing decisions. The result of double regression shows all of independent variable (image and brand awareness) give positive influenced toward Nu Green Tea's purchasing decisions. The biggest positive influenced toward Nu Green Tea's purchasing decision is on the brand awareness variable with coefficient 0,934, then it is followed by image variable with coefficient 0,085 .
\end{abstract}

Keywords: Brand Image, Brand Awareness, and Purchasing Decision.

\section{PENDAHULUAN}

Di pasar yang serba kompetitif seperti sekarang ini citra dan Kesadaran merek mempunyai peranan penting bagi kelangsungan hidup sebuah perusahaan. Merek adalah nama, istilah, tanda, symbol, atau rancangan, atau kombinasi dari semua ini yang dimaksudkan untuk mengidentifikasi produk atau jasa dari satu atau kelompok penjual dan membedakannya dari produk lain (Kotler \& Amstrong, 2001: 56).

Menurut Aaker yang dikutip dalam buku The Power of Brand karya Freddy Rangkuti (2009:39), kesadaran merek adalah kesanggupan seseorang calon pembeli untuk mengenali atau mengingat kembali bahwa suatu merek merupakan bagian dari kategori produk tertentu.

Menurut Kotler (2002:204) ada lima tahap proses terjadinya keputusan pembelian yang dilalui oleh konsumen dalam proses pembelian yaitu: pengenalan masalah, pencarian informasi, evaluasi alternatif, keputusan pembelian, perilaku pasca pembelian.

Dengan besarnya pengaruh yang diberikan oleh suatu merek yang sudah dianggap sebagai aset perusahaan (brand equity) maka PT. ABC President Indonesia selaku pemegang merek "Nu Green Tea" pastinya menginginkan merek "Nu Green 
Tea" sukses di pasaran. Salah satu indikator bahwa merek suatu produk sukses dan dikenal luas oleh masyarakat adalah masuk di dalam jajaran kategori peringkat merek nasional. Survei peringkat merek biasanya dilakukan oleh lembaga-lembaga survei yang berkompeten seperti yang dilakukan oleh majalah Marketing. Namun kenyataannya bahwa $\mathrm{Nu}$ Green Tea tidak serta merta langsung di minati oleh masyarakat untuk memutuskan sebuah pembelian " $\mathrm{Nu}$ Green Tea".

\section{RUMUSAN MASALAH}

a. Apakah citra merek berpengaruh secara positif dan signifikan terhadap keputusan pembelian teh hijau dalam kemasan " $\mathrm{Nu}$ Green Tea"?

b. Apakah kesadaran merek berpengaruh secara positif dan signifikan terhadap keputusan pembelian teh hijau dalam kemasan "Nu Green Tea"?

c. Apakah terdapat pengaruh citra merek dan kesadaran merek secara bersamasama terhadap keputusan teh hijau dalam kemasan "Nu Green Tea"?

\section{TINJAUAN TEORI}

Citra merek menurut dapat didefinisikan sebagai bentuk holistik untuk semua asosiasi merek yang berkaitan dengan merek (Sitinjak, 2005:54). Indikator dari variabel citra merek adalah sebagai berikut :

a. Mengenal simbol atau logo merek

b. Kekuatan citra merek c. Merek yang terpercaya

Kesadaran merek menurut adalah kesanggupan seorang calon pembeli untuk mengenali atau mengingat kembali bahwa suatu merek merupakan bagian dari kategori produk tertentu (Humdiana, 2005 : 156). Indikator dari variabel kesadaran merek adalah sebagai berikut :

a. Posisi merek dalam ingatan konsumen

b. Kemampuan mengenali varian produk

c. Kemampuan mengingat slogan / jingle produk

d. Asosiasi merek dengan produk

Referensi: Astuti dan Cahyadi (2007); Wening dan Suyono (2006)

Keputusan pembelian konsumen dipengaruhi oleh perilaku konsumen. Perilaku konsumen adalah tindakan yang langsung terlibat dalam mendapatkan, mengkonsumsi, serta menghabiskan produk dan jasa, termasuk proses keputusan yang mendahului dan menyusuli tindakan ini (Engel, dkk,1994 : 176). Keputusan pembelian yang dimaksud dalam penelitian ini adalah rasa percaya diri yang kuat pada diri konsumen atau pelanggan yang merupakan keyakinan bahwa keputusan atas pembelian produk teh hijau dalam kemasan siap minum "NU Green Tea" yang diambilnya adalah benar. Indikator dari variabel dependen ini adalah
a. Kemantapan dalam membeli
b. Pertimbangan dalam membeli
c. Kesesuaian atribut dengan keinginan dan kebutuhan.




\section{METODE PENELITIAN}

Jenis data yang digunakan adalah deskriptif kuantitatif dan sumber data yang digunakan adalah data primer yaitu dengan cara menyebarkan angket kepada responden kepada responden Populasi yang digunakan adalah seluruh konsumen atau pelanggan UB Barokah di jalan Jengki No. 53 Kebon Pala. Sampel yang digunakan yaitu dengan nonprobability sampling accidental atau Insidental, yaitu teknik penentuan sampel berdasarkan kebetulan atau insidental, yaitu siapa saja yang secara kebetulan bertemu dengan peneliti dapat digunakan sebagai sampel, bila dipandang orang yang kebetulan ditemui itu cocok sebagai sumber data (Sugiyono, 2012:96). Sebanyak 50 orang.

\section{PEMBAHASAN}

\section{Uji Normalitas}

Uji normalitas data dimaksudkan untuk memperlihatkan bahwah data sampel berasal dari populasi yang berdistribusi normal. Uji normalitas ini menggunakan metode Kolmogorov Smirnov. Dasar pengambilan keputusan dalam uji normalitas ini yaitu jika signifikan yang diperoleh $>0,05$ maka data sampel dari populasi tersebut berdistribusi normal, sebaliknya jika signifikan yang diperoleh $<0,05$ maka data sampel dari populasi tersebut tidak berdistribusi normal.

\section{Tabel Hasil Uji Normalitas}

One-Sample Kolmogorov-Smirnov Test

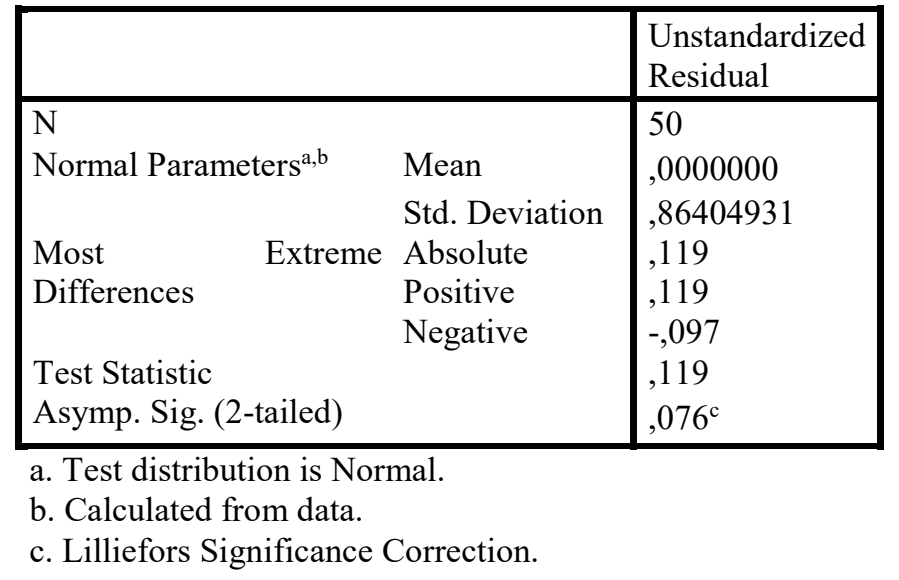

Berdasarkan hasil output SPSS diatas, diketahui bahwa nilai signifikan sebesar 0,076 lebih besar dari 0,05 atau $(0,76>05)$, sehingga dapat disimpulkan bahwa data sampel dari populasi yang diuji berdistribusi normal.
Uji linearitas bertujuan untuk mengetahui apakah dua variabel atau lebih yang diuji mempunyai hubungan yang linear atau tidak secara signifikan. Uji ini biasanya digunakan sebagai persyarat dalam analisis kolerasi atau regresi linear. Dasar

\section{Uji Linearitas}


pengambilan keputusan dalam uji linearitas adalah:

- Jika nilai probabilitas $>0,05$ maka hubungan antara variable $(\mathrm{X})$ dengan $(\mathrm{Y})$ adalah linear.
- Jika nilai probabilitas $<0,05$ maka hubungan antara variable $(\mathrm{X})$ dengan $(\mathrm{Y})$ adalah tidak linear.

Tabel Uji Linearitas $X_{1}$ dengan $Y$

ANOVA Table

\begin{tabular}{|c|c|c|c|c|c|c|c|}
\hline & & & $\begin{array}{l}\text { Sum of } \\
\text { Squares }\end{array}$ & Df & $\begin{array}{l}\text { Mean } \\
\text { Square }\end{array}$ & $\mathrm{F}$ & Sig. \\
\hline \multirow{5}{*}{$\begin{array}{l}\text { Keputusan_P } \\
\text { embelian } \\
\text { citra_merek }\end{array}$} & \multirow{3}{*}{$\begin{array}{l}\text { Between } \\
* \text { Groups }\end{array}$} & (Combined) & 78,358 & 10 & 7,836 & 1,433 & 203 \\
\hline & & Linearity & 43,114 & 1 & 43,114 & 7,882 & ,008 \\
\hline & & $\begin{array}{l}\text { Deviation from } \\
\text { Linearity }\end{array}$ & 35,244 & 9 & 3,916 & ,716 & ,691 \\
\hline & \multicolumn{2}{|c|}{ Within Groups } & 213,322 & 39 & 5,470 & & \\
\hline & \multicolumn{2}{|l|}{ Total } & 291,680 & 49 & & & \\
\hline
\end{tabular}

Berdasarkan hasil output diatas terdapat hubungan linear secara signifikan diperoleh nilai $\mathrm{F}_{\text {hitung }}$ sebesar 0,716 dengan antara variabel citra merek (X1) dengan tingkat signifikan atau probabilitas sebesar variable keputusan pembelian (Y) 0,691 lebih besar dari 0,05 yang artinya

Tabel Uji Linearitas $X_{2}$ dengan $Y$ ANOVA Table

\begin{tabular}{|c|c|c|c|c|c|c|c|}
\hline & & & $\begin{array}{l}\text { Sum of } \\
\text { Squares }\end{array}$ & Df & $\begin{array}{l}\text { Mean } \\
\text { Square }\end{array}$ & $\mathrm{F}$ & Sig. \\
\hline \multirow{5}{*}{$\begin{array}{l}\text { Keputusan } \\
\text { Pembelian * } \\
\text { kesadaran_- } \\
\text { Merek }\end{array}$} & \multirow{3}{*}{$\begin{array}{l}\text { Between } \\
\text { Groups }\end{array}$} & (Combined) & 256,069 & 6 & 42,678 & $\begin{array}{r}51,53 \\
3\end{array}$ &, 000 \\
\hline & & Linearity & 250,186 & 1 & $\begin{array}{r}250,18 \\
6\end{array}$ & $\begin{array}{r}302,0 \\
96\end{array}$ &, 000 \\
\hline & & $\begin{array}{l}\text { Deviation } \\
\text { Linearity }\end{array}$ & 5,883 & 5 & 1,177 & 1,421 & ,236 \\
\hline & \multicolumn{2}{|c|}{ Within Groups } & 35,611 & 43 &, 828 & & \\
\hline & \multicolumn{2}{|l|}{ Total } & 291,680 & 49 & & & \\
\hline
\end{tabular}

Berdasarkan hasil output diatas dengan variabel Keputusan Pembelian (Y). diperoleh nilai $F_{\text {hitung sebesar 1,421 dengan }}$ tingkat signifikan atau probabilitas sebesar 0,236 lebih besar dari 0,05 yang artinya terdapat hubungan linear secara signifikan antara variabel Kesadaran Merek (X2)

\section{Pengujian Hipotesis}

\section{Koefisien Korelasi}

Untuk menentukan suatu besaran yang menyatakan kuat atau lemahnya hubungan variabel citra merek $\left(\mathrm{X}_{1}\right)$, kesadaran merek 
$\left(\mathrm{X}_{2}\right)$, dengan keputusan pembelian $(\mathrm{Y})$ maka dilakukan perhitungan koefisien korelasi product moment yang diolah dengan SPSS

22.0 dapat dilihat pada tabel ini

\section{Koefisien Korelasi}

Correlations $^{\mathrm{b}}$

\begin{tabular}{|lll|r|r|r|}
\hline & & $\begin{array}{l}\text { Citra_M } \\
\text { erek }\end{array}$ & $\begin{array}{c}\text { Kesadaran } \\
\text { Merek }\end{array}$ & $\begin{array}{l}\text { Keputusan } \\
\text { Pembelian }\end{array}$ \\
\hline $\begin{array}{l}\text { Spearman' } \\
\text { s rho }\end{array}$ & Citra_Merek & $\begin{array}{l}\text { Correlation } \\
\text { Coefficient } \\
\text { Sig. (2-tailed) }\end{array}$ & 1,000 &, 127 &, $374^{* *}$ \\
& &. &, 379 &, 007 \\
\cline { 2 - 6 } & Kesadaran_Merek & $\begin{array}{l}\text { Correlation } \\
\text { Coefficient }\end{array}$ &, 127 & 1,000 &, $739^{* *}$ \\
& Sig. (2-tailed) &, 379 &. &, 000 \\
\cline { 2 - 6 } & Keputusan_Pemb & $\begin{array}{l}\text { Correlation } \\
\text { Coefficient } \\
\text { Sig. (2-tailed) }\end{array}$ &, $374^{* *}$ &, $739^{* *}$ & 1,000 \\
& &, 007 &, 000 & \\
\hline
\end{tabular}

**. Correlation is significant at the 0.01 level (2-tailed).

b. Listwise $\mathrm{N}=50$

Dari perhitungan koefisien korelasi product moment diatas dan berdasarkan tabel pedoman untuk memberikan interprestasi koefisien korelasi menunjukan bahwa koefisien korelasi untuk citra merek sebesar 0,374 dan kesadaran merek sebesar 0,739 menujukkan hubungan yang tinggi terhadap keputusan pembelian, sementara keputusan pembelian 1,000 menujukkan hubungan yang kuat dengan citra merek dan kesadaran merek.

\section{Analisis Persamaan Regresi Linear}

\section{Sederhana.}

Untuk mengetahui seberapa besar hubungan variabel citra merek denganvariabel keputusan pembelian pada $\mathrm{Nu}$ green tea, maka digunakan perhitungan persamaan regresi linier sederhana. Hasil regresi linier sederhana dapat dilihat dari data yang diolah dengan Program SPSS versi 22.0

Tabel Persamaan Regresi Linear Sederhana $X_{1}$ dengan $Y$

Coefficients $^{\mathrm{a}}$

\begin{tabular}{|c|c|c|c|c|c|c|}
\hline \multirow{2}{*}{\multicolumn{2}{|c|}{ Model }} & \multicolumn{2}{|c|}{ Unstandardized Coefficients } & \multirow{2}{*}{$\begin{array}{c}\begin{array}{c}\text { Standardized } \\
\text { Coefficients }\end{array} \\
\text { Beta }\end{array}$} & \multirow[b]{2}{*}{$\mathrm{t}$} & \multirow[b]{2}{*}{ Sig. } \\
\hline & & $\mathrm{B}$ & Std. Error & & & \\
\hline \multirow[t]{2}{*}{1} & (Constant) & 11,832 & 3,166 & & 3,737 &, 000 \\
\hline & Citra merek & 241 & 084 & ,384 & 2,885 & 006 \\
\hline
\end{tabular}

a. Dependent Variable: Keputusan_Pembelian

Persamaan regresi berdasarkan nilai koefisien diatas adalah konstan (a) $=11,832$ dan koefisien regresi(b) $=0,241$. Maka persamaan regresinya dapat di tuliskan

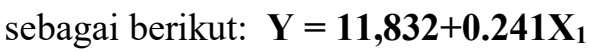


Artinya bila nilai citra merek bertambah 1 , keputusan pembelian sebesar 0,241, pada arah maka akan mengakibatkan peningkatan pada yang sama dengan konstanta 11,832.

Tabel Persamaan Regresi Linear Sederhana $X_{2}$ Dengan $Y$

Coefficients $^{\mathrm{a}}$

\begin{tabular}{|c|c|c|c|c|c|}
\hline \multirow[b]{2}{*}{ Model } & \multicolumn{2}{|c|}{$\begin{array}{c}\text { Unstandardized } \\
\text { Coefficients } \\
\end{array}$} & $\begin{array}{l}\text { Standardized } \\
\text { Coefficients }\end{array}$ & \multirow[b]{2}{*}{$\mathrm{T}$} & \multirow[b]{2}{*}{ Sig. } \\
\hline & B & Std. Error & Beta & & \\
\hline $\begin{array}{ll}1 & \text { (Constant) } \\
& \text { Kesadaran Merek }\end{array}$ & $\begin{array}{l}, 477 \\
, 973\end{array}$ & $\begin{array}{r}1,209 \\
, 057\end{array}$ & ,926 & $\begin{array}{r}394 \\
17,012\end{array}$ & $\begin{array}{l}, 695 \\
, 000\end{array}$ \\
\hline
\end{tabular}

a. Dependent Variable: Keputusan_Pembelian

Persamaan regresi berdasarkan nilai koefisien diatas adalah konstan (a) $=0,477$ dan koefisien regresi(b) $=0,973$. Maka persamaan regresinya dapat di tuliskan sebagai berikut: $Y=\mathbf{0 , 4 7 7 + 0 . 9 7 3 X _ { 2 }}$

Artinya bila nilai kesadaran merek bertambah 1, maka akan mengakibatkan peningkatan pada keputusan pembelian sebesar 0,973 , pada arah yang sama dengan konstanta 0,477 .

\section{Analisis Regresi Linear Berganda}

Regresi linear berganda bertujuan untuk mengetahui koefisien regresi terhadap dua variable atau lebih, dengan hasil pengolahan data sebagai berikut:

\section{Tabel Regresi Linear Berganda}

Coefficients $^{\mathrm{a}}$

\begin{tabular}{|c|c|c|c|c|c|c|}
\hline & \multirow[b]{2}{*}{ Model } & \multicolumn{2}{|c|}{$\begin{array}{c}\text { Unstandardized } \\
\text { Coefficients }\end{array}$} & \multirow{2}{*}{$\begin{array}{c}\text { Standardized } \\
\text { Coefficients } \\
\text { Beta }\end{array}$} & \multirow[b]{2}{*}{$\mathrm{t}$} & \multirow[b]{2}{*}{ Sig. } \\
\hline & & $\mathrm{B}$ & Std. Error & & & \\
\hline \multirow[t]{3}{*}{1} & (Constant) & $-1,882$ & 1,482 & & $-1,269$ & ,211 \\
\hline & Citra_Merek &, 085 &, 034 & , 135 & 2,512 &, 015 \\
\hline & Kesadaran Merek & ,934 &, 057 &, 888 & 16,503 &, 000 \\
\hline
\end{tabular}

a. Dependent Variable: Keputusan_Pembelian

Dari hasil penelitian maka dapat diperoleh persamaan regresi berganda adalah sebagai berikut :

$$
Y=-1.882+0,085 X 1+0,934 X 2
$$

Keterangan:

$\mathrm{Y}=$ Keputusan Pembelian

$\mathrm{X} 1=$ Citra Merek

$\mathrm{X} 2$ = Kesadaran Merek

Dari persamaan tersebut dapat dijelaskan bahwa: a. Nilai Kostata sebesar -1.882 artinya apabila tidak ada Citra dan Kesadaran merek atau dengan kata lain cita merek (X1) dan Kesadaran Merek (X2) nilainya 0 maka keputusan pembelian (Y) Sebesar -1.882. maka dapat disimpulkan konsumen dalam memutuskan membeli $\mathrm{Nu}$ Green Tea tanpa didukung informasi Citra dan Kesadaran Merek maka 
konsumen bingung dalam membeli (kebingungan dalam memilih produk )

b. $\mathrm{X}^{1}$ : Koefisien regresi variabel Citra Merek sebesar 0,085 artinya jika variabel Citra Merek mengalami kenaikan 1\% maka keputusan pembelian akan mengalami kenaikan sebanyak $8,5 \%$ pada arah yang sama dengan konstanta 1.882 .

c. $\mathrm{X}^{2}$ : Koefisien regresi Kesadaran Merekse besar 0,934 artinya jika variabel kesadaran Merek bertambah 1\% maka keputusan pembelian akan mengalami kenaikan sebanyak $93,4 \%$ pada arah yang sama dengan konstanta 1.882 .

\section{Uji Hipotesis Secara Simultan (Uji F)}

Tabel Uji Hipotesis Secara Simultan (Uji F) ANOVA $^{\mathrm{a}}$

\begin{tabular}{|c|c|c|c|c|c|c|}
\hline & Model & $\begin{array}{l}\text { Sum of } \\
\text { Squares }\end{array}$ & Df & Mean Square & $\mathrm{F}$ & Sig. \\
\hline \multirow[t]{3}{*}{1} & Regression & 255,098 & 2 & 127,549 & 163,871 &, $000^{\mathrm{b}}$ \\
\hline & Residual & 36,582 & 47 & ,778 & & \\
\hline & Total & 291,680 & 49 & & & \\
\hline
\end{tabular}

a. Dependent Variable: Keputusan Pembelian

b. Predictors: (Constant), Citra_Merek, Kesadaran_Merek

Pada hasil output diatas nilai baris Regression pada kolom signifikansi (sig) diatas diperoleh nilai 0,000 , artinya adalah nilai signifikansi lebih kecil $0,000<0,05$ maka dapat disimpulkan bahwa variabel Citra Merek dan Kesadaran Merek berpengaruh signifikan terhadap variabel Keputusan Pembelian.

\section{Koefisien Determinasi}

Tabel Hasil Koefisien Determinasi

Model Summary

\begin{tabular}{|l|r|r|r|r|}
\hline Model & \multicolumn{1}{|c|}{$\mathrm{R}$} & R Square & $\begin{array}{c}\text { Adjusted R } \\
\text { Square }\end{array}$ & $\begin{array}{c}\text { Std. Error of the } \\
\text { Estimate }\end{array}$ \\
\hline 1 &, $935^{\mathrm{a}}$ &, 875 &, 869 &, 882 \\
\hline
\end{tabular}

a. Predictors: (Constant), Citra_Merek, Kesadaran_Merek

Berdasarkan hasil perhitungan koefisien determinasi (R Square) sebesar 0,875. Nilai tersebut menunjukan bahwa konstribusi citra merek dan kesadaran merek terhadap keputusan pembelian konsumen pada $\mathrm{Nu}$ Green Tea adalah sebesar $87,5 \%$ sedangkan sisanya sebesar $12,5 \%$ dipengaruhi faktor lain yang mempengaruhi keputusan pembelian yang tidak dibahas dalam penelitian.

\section{KESIMPULAN DAN SARAN}

KESIMPULAN 
Dari pembahasan yang telah diuraikan, maka dapat ditarik kesimpulan sebagai berikut :

1. Citra merek Dan hasil pengujian hipotesis H1 telah membuktikan tidak terdapat hubungan yang signifikan antara citra merek (X1) dengan Keputusan pembelian (Y). Dilihat dari perhitungan yang telah dilakukan diperoleh nilai koefisien sebesar 0,085 dan thitung sebesar 2,512 dengan taraf signifikansi 0,015 lebih besar dari 0,05 , yang berarti bahwa hipotesis penelitian ini menerima Ho dan menolak Ha. Dengan demikian dapat berarti bahwa hipotesis H1 "Citra Merek berpengaruh positif terhadap keputusan pembelian konsumen" diterima.

2. Kesadaran merek dapat dilihat dari beberapa Dimensi yang terdiri dari posisi merek dalam benak konsumen, kemampuan mengenali produk, kemampuan mengingat slogan dan jingle produk, asosiasi merek dengan produk. Berdasarkan analisis deskriptif yang telah dilakukan maka diperoleh nilai rekapitulasi nilai tanggapan responden atas indikator variabel kesadaran merek dapat dilihat dari hasil penilaian rata-rata, dimana nilai ini termasuk dalam kategori baik. Dan hasil pengujian hipotesis $\mathrm{H} 2$ membuktikan bahwa Kesadaran merek (X2) memiliki hubungan yang positif dengan Keputusan pembelian (Y). Dilihat dari perhitungan yang telah dilakukan diperoleh nilai koefisien sebesar 0,934 dan thitung sebesar 16,503 dengan taraf signifikansi 0,000 . Taraf signifikansi hasil sebesar 0,000 tersebut lebih kecil dari 0,05, yang berarti bahwa hipotesis dalam penelitian ini menerima $\mathrm{Ha}$ dan menolak Ho. Dengan demikian dapat berarti bahwa hipotesis H2 "kesadaran merek mempunyai pengaruh positif terhadap keputusan pembelian konsumen" diterima.

3. Keputusan Pembelian dapat dilihat dari beberapa dimensi yang terdiri dari, kemantapan dalam membeli, pertimbangan dalam membeli, kesesuaian atribut dengan kebutuhan dan keinginan. Berdasarkan analisis deskriptif yang telah dilakukan maka diperoleh rekapitulasi nilai tanggapan responden atas indikator variabel keputusan pembelian dapat dilihat dari penilaian rata-rata, dimana nilai ini termasuk dalam kategori baik. Dan hasil pengujian hipotesis secara simultan membuktikan bahwa citra merek (X1) dan kesadaran merek (X2) memiliki pengaruh yang signifikan terhadap keputusan pembelian (Y) dilihat dari perhitungan yang dilakukan diperoleh nilai (sig) 0.000. yang artinya lebih kecil dari 0,05 . Maka dapat disimpulkan bahwa citra merek dan kesadaran merek berpengaruh secara signifikan terhadap keputusan pembelian.

\section{SARAN}

Dari kesimpulan diatas maka saran saya selaku peneliti adalah sebaiknya PT ABC 
dapat lebih meningkatkan citra merek $\mathrm{Nu}$ green tea agar dapat mempengaruhi keputusan pembelian konsumen secara lebih signifikan, sehingga citra merek $\mathrm{Nu}$ Green Tea dapat terbangun lebih baik lagi, lebih dihargai, dan mampu meningkatkan kepuasan pelanggan PT. ABC sehingga apabila citra merek dan kesadaran merek sebuah perusahaan semakin baik maka dapat dipastikan kepuasan pelanggan akan meningkat dan dapat mempengaruhi keputusan pembelian konsumen secara signifikan sehingga perusahaan akan mendapat profit yang lebih tinggi.

\section{DAFTAR PUSTAKA}

Aaker, David. (1997). Manajemen Ekuitas Merek. Jakarta: Spektrum.

Amstrong, 2001, Prinsip-Prinsip Manajemen, Jilid 1 Edisi Kedelapan, Alih Bahasa, Oleh Damos Sihombing, Jakarta: Penerbit Erlangga.

Bilson Simamora. 2003. Panduan Riset Perilaku Konsumen. Jakarta: PTGramedia Pustaka Utama.

Engel, James F, et.al, 1994, Consumer Behavior, Jilid 1, Alih Bahasa Budiyanto, Jakarta: Penerbit Binarupa Aksara.

Fandy Tjiptono. 1995. Strategi Pemasaran. Yogyakarta: Andi Offset.

Humdiana. 2005. Analisis Elemen-elemen Merek. Jurnal of Marketing Manajemen,Vol. 12, No. 1.
,2005. Strategi Pemasaran. Jakarta: PT. Gramedia Pustaka Mizan Pustaka.

Kotler, Philip. 2002. Manajemen Pemasaran Edisi Millenium 2 (Diterjemahkan Oleh Hendra Teguh dan Ronny A. Rusli). Jakarta: PT. Prenhalindo.

Kotler, Philip dan Keller, Kevin Lane. 2007. Manajemen Pemasaran, Edisi 12, Jilid 1, Jakarta: PT.Indeks.

Nicolino, Patricia. F. 2004. Brand Management (The Complete Ideal's Guide). Jakarta: Prenada Media.

Praba, Sulistyawati. 2009. Analisis Pengaruh Citra Merek Dan Kualitas Produk Terhadap Keputusan Pembelian. Jurnal Administrasi dan Bisnis. Vol 16, No 2 (2009).

Setiadi, Nugroho. J. 2003. Perilaku Konsumen dalam Konsep dan Impilikasi untuk Strategi Penelitian dan Pemasaran. Jakarta: Prenada Media.

Tjiptono, Fandy. 2005. Pemasaran Jasa, Malang: Bayumedia Publishing

Tumpal dan Sitinjak. 2005. Pengaruh Citra Merek dan Sikap Merek Terhadap Ekuitas Merek. Jurnal Ekonomi Perusahaan, Vol 12., No.2 Juni 2005. 